medRxiv preprint doi: https://doi.org/10.1101/2020.07.11.20151480; this version posted July 14, 2020. The copyright holder for this preprint

(which was not certified by peer review) is the author/funder, who has granted medRxiv a license to display the preprint in perpetuity.

It is made available under a CC-BY-NC-ND 4.0 International license.

\title{
Effects of Smoking and Smoking Cessation on the Intestinal Microbiota
}

Short Title: Smoking and the Intestinal Microbiota

\begin{abstract}
Marcus G. Sublette, MDa; Tzu-Wen L. Cross, PhD, RD ; Claudia E. Korcarz, DVMa; Kristin M. Hansen, BSa; Sofia M. Murga-Garrido, MD ${ }^{\text {; }}$ Stanley L. Hazen, MD, PhDc; Zeneng Wang, $\mathrm{PhD}^{\mathrm{c}}$; Madeline K. Oguss, $\mathrm{MS}^{\mathrm{a}}$, Federico E. Rey, $\mathrm{PhD}^{\mathrm{b}}$; James H. Stein, MD, ${ }^{a}$

aUniversity of Wisconsin School of Medicine and Public Health, Madison, WI, USA bDepartment of Bacteriology, University of Wisconsin, Madison, WI, USA

'Department of Cardiovascular and Metabolic Sciences, Lerner Research Institute, Cleveland Clinic, Cleveland, OH, USA
\end{abstract}

\author{
Corresponding Author: \\ James H. Stein, MD \\ University of Wisconsin School of Medicine and Public Health \\ Department of Medicine, Division of Cardiovascular Medicine \\ H4/520 Clinical Science Center \\ 600 Highland Avenue, MC 3248 \\ Madison, WI 53792 \\ Phone: 608-262-2075 \\ Fax: 608-263-0405 \\ Email: jhs@medicine.wisc.edu
}

Word Count: 1961

Tables: 2

Supplementary Figure: 1

\author{
Keywords: \\ Smoking \\ Smoking cessation \\ Microbiome
}


medRxiv preprint doi: https://doi.org/10.1101/2020.07.11.20151480; this version posted July 14, 2020. The copyright holder for this preprint (which was not certified by peer review) is the author/funder, who has granted medRxiv a license to display the preprint in perpetuity. It is made available under a CC-BY-NC-ND 4.0 International license .

\begin{abstract}
Introduction

We evaluated associations of smoking heaviness markers and the effects of smoking cessation on the intestinal microbiota and cardiovascular disease risk factors in current smokers undertaking a quit attempt.

\section{Methods and Results}

Participants were current smokers enrolled in a randomized clinical trial of smoking cessation therapies with visits, risk factor measurements, and fecal collections at baseline, 2, and 12 weeks after starting a quit attempt. Genomic DNA was extracted from fecal samples followed by 16S rRNA gene sequencing and analysis using the QIIME2 software workflow. Relative abundances of bacterial taxa and alpha- and beta- diversity measures were compared.

Longitudinal changes in bacterial taxa abundances were compared using analysis of covariance (ANCOVA). The 36 smokers were (mean [standard deviation]) 51.5 (11.1) years old (42\% male) and smoked 15.1 (6.4) cigarettes per day for 22.7 (11.9) pack-years. Their exhaled carbon monoxide (CO) levels were 17.6 (9.3) ppm. At baseline, relative abundances of the phylum Actinobacteria were correlated inversely with pack-years (rho $=-0.44, p=0.008)$ and Cyanobacteria were correlated positively with $\mathrm{CO}$ levels ( $\mathrm{rho}=0.39, \mathrm{p}=0.021$ ). After 12 weeks, abundances of the phylaBacteroidetes increased $\left(p_{\text {ANCOVA }}=0.048\right)$ and Firmicutes decreased $\left(p_{\text {ANCOVA }}=0.036\right)$ among abstainers compared to continuing smokers. Increases in alphadiversity were associated with lower heart rates $(r h o=-0.59, p=0.037)$, systolic blood pressures (rho=-0.58, $p=0.043$ ), and C-reactive protein levels ( $r h o=-0.60, p=0.034$ ).
\end{abstract}

\title{
Conclusions
}

Smoking cessation leads to minor changes in the intestinal microbiota. It is unclear if the proven health benefits of smoking cessation lead to salutary changes in the intestinal microbiota and if such changes affect cardiovascular disease risk.

\author{
Key Words \\ Gut flora \\ Microbiome \\ Smoking \\ Smoking cessation
}

\section{Implications}

In the largest prospective study of current smokers making a quit attempt to date, we showed that smoking cessation has minor effects on the composition of the gut microbiome. In successful abstainers, relative abundances of the phyla Bacteroidetes increased and Firmicutes decreased, a pattern of uncertain clinical significance. We did not observe significant changes in alpha- or beta-diversity with smoking cessation. It is unclear if the proven health benefits of smoking cessation lead to salutary changes in the intestinal microbiota and if such changes affect cardiovascular disease risk. 
medRxiv preprint doi: https://doi.org/10.1101/2020.07.11.20151480; this version posted July 14, 2020. The copyright holder for this preprint

(which was not certified by peer review) is the author/funder, who has granted medRxiv a license to display the preprint in perpetuity.

It is made available under a CC-BY-NC-ND 4.0 International license .

\section{INTRODUCTION}

The gut microbiota appears to play a pathophysiologic role in atherosclerosis and cardiovascular disease, possibly through interactions with the immune system resulting in chronic systemic inflammation, by contributions to lipid metabolism, and/or through direct interactions of microbial-derived products such as trimethylamine $\mathrm{N}$-oxide (TMAO) with vascular endothelium and platelets.[1,2] Cigarette smoke may modulate gut microbiota by upregulating oxidative stress-related enzymes in gut immune tissue, altering the gut mucin layer, expression of intestinal tight junction proteins, and local acid/base imbalance in the colon, through direct toxic effects from the myriad compounds in tobacco smoke, or through the spread of bacteria directly from cigarettes.[3,4] Although there is evidence that the intestinal microbiota of smokers differs from non-smokers, $[5,6]$ it is not known whether smoking cessation changes the gut microbiota and how these changes may relate to pre-quit smoking heaviness, weight gain, and cardiovascular disease risk factors. A previous report described profound changes in the intestinal microbiota following smoking cessation, however that was a very small study and the observed microbiome changes were not integrated with vascular and inflammatory biomarkers.[3,5,6]

In this pilot study, we sought to identify plausible associations between smoking heaviness, metabolic markers, and the composition of the intestinal microbiota and their changes 12 weeks after a quit attempt. In contrast with the previous published work, $[3,5,6]$ our results suggest that smoking cessation is associated with minor changes in the gut microbiome.

\section{METHODS \\ Participants}

The University of Wisconsin Health Sciences Institutional Review Board approved this study. This study was conducted in accordance with all University, State, and Federal research regulations. All participants provided free informed consent. Participants were recruited from the ongoing Quitting Using Intensive Treatment Study (QUITS) Trial (NCT03176784) and enrolled from February $19^{\text {th }}$ to August $16^{\text {th }}, 2019$. The main QUITS inclusion criteria were age $\geq 18$ years old, smoking $\geq 10$ cigarettes per day, and no use of pipe tobacco, cigars, snuff, ecigarettes or chewing tobacco in the preceding 30 days. This sub-study also excluded individuals with factors known to affect the gut microbiota including: use of systemic antibiotics, corticosteroids, immunomodulators, or commercial probiotics in the last 6 months, major gastrointestinal surgery, and active inflammatory bowel disease or other gastrointestinal disorders.

\section{Design}

All participants received varenicline ( $1 \mathrm{mg}$ daily) and either placebo or nicotine patches (14 $\mathrm{mg}$ for 2 weeks pre-quit and then 10 weeks post-quit, then $7 \mathrm{mg}$ patches for weeks 11 and 12 after the quit date). Smoking cessation was confirmed by 7-day self-report and verified by exhaled carbon monoxide (CO, Micro ${ }^{+\mathrm{TM}}$ Smokerlyzer $^{\circledR} \mathrm{CO}$ monitor, Bedfont Scientific Ltd, Maidstone, Kent, England) levels. Participant measures were obtained at baseline (immediately prior to the quit attempt), 2 weeks post-quit attempt, and 12 weeks post-quit attempt.

\section{Processing and Analysis of Fecal Samples}

Fresh stool samples were collected by participants and kept refrigerated $\left(4-8^{\circ} \mathrm{C}\right)$ until delivery to the microbiology lab where an aliquot of feces was immediately stored at $-80^{\circ} \mathrm{C}$ until further processing. Fecal samples were kept refrigerated for an average of 3 hours and 43 minutes between collection to storage, ranging from 40 minutes to 8 hours and 5 minutes. 
medRxiv preprint doi: https://doi.org/10.1101/2020.07.11.20151480; this version posted July 14, 2020. The copyright holder for this preprint (which was not certified by peer review) is the author/funder, who has granted medRxiv a license to display the preprint in perpetuity. It is made available under a CC-BY-NC-ND 4.0 International license .

Genomic DNA was extracted from fecal aliquots using a bead-beating protocol.[7] Briefly, feces was re-suspended in a solution containing $500 \mu \mathrm{l}$ of extraction buffer [200 mM Tris (pH 8.0), $200 \mathrm{mM} \mathrm{NaCL}, 20 \mathrm{mM}$ EDTA], $210 \mu \mathrm{l}$ of $20 \%$ SDS, $500 \mu \mathrm{l}$ phenol:chloroform:isoamyl alcohol (pH 7.9, 25:24:1, Invitrogen, Carlsbad, CA) and $500 \mu \mathrm{l}$ of 0.1-mm diameter zirconia/silica beads. Samples were mechanically disrupted using a bead beater (BioSpec Products, Barlesville, OK; maximum setting for 3 minutes at room temperature), followed by centrifugation, recovery of the aqueous phase, and precipitation with sodium acetate and isopropanol. QIAquick 96-well PCR Purification Kit (Qiagen, Germantown, MD) was used to remove contaminants. Isolated DNA was eluted in Tris-EDTA buffer and stored at $-80^{\circ} \mathrm{C}$ until further use.

\section{Sequencing}

PCR was performed using universal primers flanking the variable 4 (V4) region of the bacterial 16S rRNA gene.[16] PCR products were purified with the QIAquick 96-well PCR Purification Kit (Qiagen, Germantown, MD). Samples were quantified by Qubit Fluorometer (Invitrogen, Carlsbad, CA) and equimolar pooled. The pool was sequenced at the University of Wisconsin-Madison Biotechnology Center with the MiSeq 2x250 v2 kit (Illumina, San Diego, CA, USA). DNA extraction blanks, PCR blanks, and technical duplications for both extractions and PCRs were employed to ensure proper sample handling throughout library preparation process.

\section{Analysis}

Sequences were processed using QIIME 2 pipeline (2019.1).[8] Briefly, demultiplexed paired-end sequences were imported using Casava 1.8 format and denoised using DADA2[9] to obtain amplicon sequence variant (ASV) table. Singletons (ASV that were observed fewer than 2 times) and ASVs that are present in less than $10 \%$ of the samples were discarded. A naive Bayes taxonomy classifier was trained on the Greengenes[10] reference database (clustered at $99 \%$ similarity). This classifier was used to assign taxonomy to ASV.[11] ASV were then collapsed based on genus-level taxonomy. An even sampling depth (sequences per sample) of 4,135 sequences per sample was used for assessing alpha- and beta-diversity measures. Pielou's evenness index,[12] Faith's phylogenetic diversity (PD), and Shannon diversity index were used to measure alpha diversity. Beta-diversity was calculated using Bray-Curtis, Jaccard, and weighted and unweighted UniFrac metrics.[13]

\section{Statistical Analysis}

All analyses used XLStat (Addinsoft, France) in R (R Core Team, 2014). Distributions were inspected for zero values and non-linearity. Spearman's rank correlations were used to compare relative abundances of microbial taxonomy, smoking heaviness markers, and other measures at baseline. ANCOVA was used to compare temporal changes in intestinal microbiota abundances and diversity measures by eventual cessation group (abstainers vs. continuing smokers) and each baseline measure. Given the exploratory nature of our study, we estimated statistical power using the genus taxonomic level with up to 13 different categories. With a sample of size of 30 , we had $80 \%$ power to detect a rank correlation of 0.57 between the abundance metrics and outcome measures using a two-sided test for significance at a taxonomic family-wise 0.05 level, however we did not perform formal adjustments for multiple comparisons.

\section{RESULTS \\ Participant Characteristics (Table 1)}

The 36 smokers that attended the baseline visit were mean (standard deviation) 51.5 (11.1) years old, $58 \%$ female, and they smoked 15.1 (6.4) cigarettes per day for 22.7 (11.9) packyears. Their exhaled CO levels were $17.6(9.3) \mathrm{ppm}$. Greengenes classifier assigned usable 
medRxiv preprint doi: https://doi.org/10.1101/2020.07.11.20151480; this version posted July 14, 2020. The copyright holder for this preprint (which was not certified by peer review) is the author/funder, who has granted medRxiv a license to display the preprint in perpetuity. It is made available under a CC-BY-NC-ND 4.0 International license .

101

102

103

104

105

106

107

108

109

110

raw reads to 11 phyla, 35 families, and 55 genera. The most abundant phyla were Firmicutes and Bacteroidetes.

\section{Baseline Correlations between Microbial Diversity Scores, Bacterial Taxa Abundances and Smoking Measures}

Pack-years of cigarettes smoked correlated inversely with relative abundance of Actinobacteria (rho $=-0.44, \mathrm{p}=0.008$ ) and exhaled $\mathrm{CO}$ correlated positively with relative abundance of Cyanobacteria $(r h o=0.39, p=0.021)$. No significant associations between Actinobacteria or Cyanobacteria and smoking measures were identified, nor were taxa at the family or genus levels within these two phyla. The relative abundance of the Actinobacteria phylum correlated inversely with age (rho $=-0.44, \mathrm{p}=0.007)$ and carotid artery plaque score (rho=-0.33, $\mathrm{p}=0.049$ ) and directly with glucose $(\mathrm{rho}=0.038, \mathrm{p}=0.021)$. Actinobacteria and Cyanobacteria were not associated with TMAO, hsCRP, or any other cardiovascular disease risk measures. Exhaled CO was associated with the genus Dorea (rho=0.43 p=0.009), otherwise, none of the smoking heaviness measures were associated with other diversity index or bacterial abundances at the phyla, family, or genera levels.

\section{Effects of Smoking Cessation and Continued Smoking (Table 2, Supplementary Figure)}

Of the 29 participants that returned for the week 2 visit, 17 had quit smoking. There were no significant between-groups differences in relative abundances of bacteria or diversity measures at this early time point. Of the 26 that returned for the week 12 visit, 14 successfully quit smoking. Those who quit had greater reductions in exhaled $\mathrm{CO}$ levels than continuing smokers $\left(-14.0\right.$ [10.4] vs. $\left.+2.1[7.6] \mathrm{ppm}, \mathrm{p}_{\mathrm{ANCOVA}}<0.001\right)$. Significant between group differences in changes were not observed for cardiovascular disease risk factors, hsCRP, TMAO, PWV, and brachial artery FMD. Significant between group differences were not observed for relative abundances of Actinobacteria ( $\mathrm{p}_{\mathrm{ANCOVA}}=0.150$ ) or Cyanobacteria $\left(\mathrm{p}_{\mathrm{ANCOVA}}=0.165\right)$. However, Bacteroidetes increased $\left(p_{\text {ANCOVA }}=0.048\right)$ and Firmicutes decreased $\left(p_{A N C O V A}=0.036\right)$ among successful abstainers compared to continuing smokers. No other significant changes between groups were identified for relative abundances of bacteria at the phylum level.

Within Firmicutes, an undefined family within the order Clostridiales had a significant difference in abundance between smoking status groups at week 12 ( $p_{\text {ANCOVA }}=0.043$ ). At the genus level, Ruminococcus ( $\mathrm{p}_{\mathrm{ANCOVA}}=0.027$ ) and an undefined genus within order Clostridiales ( $p_{\text {ANCOVA }}=0.043$ ) also had significant differences in abundances between smoking status groups. Although changes in alpha- and beta-diversity measures over time did not differ between successful abstainers and continuing smokers, increases in alpha-diversity 12 weeks following a smoking cessation attempt were associated with lower heart rates (rho $=-0.59$, $\mathrm{p}=0.037$ ), systolic blood pressures ( $\mathrm{rho}=-0.58, \mathrm{p}=0.043$ ), and C-reactive protein ( $\mathrm{rho}=-0.60$, $p=0.034)$.

As expected, nicotine patch users were more successful at quitting with greater reductions in $\mathrm{CO}$ at week 12 visit $(p=0.006)$, however there were no significant differences in the gut microbiota between participants that received a placebo or a nicotine patch.

\section{Discussion}

In this pilot study of daily cigarette smokers, pack-years of smoking were inversely correlated with relative abundances of Actinobacteria and exhaled CO levels were inversely correlated with the abundances of Cyanobacteria. The number of cigarettes smoked per day was not associated with any bacterial taxa at the phylum level. Relative abundances of these bacteria were not associated with plasma TMAO, cardiovascular disease risk factors, or arterial measures. After a quit attempt, successful abstainers had significantly lower exhaled CO levels, but we did not observe significant changes in TMAO levels. We also did not observe between group differences in relative abundances of Actinobacteria or Cyanobacteria. Our primary 
medRxiv preprint doi: https://doi.org/10.1101/2020.07.11.20151480; this version posted July 14, 2020. The copyright holder for this preprint (which was not certified by peer review) is the author/funder, who has granted medRxiv a license to display the preprint in perpetuity. It is made available under a CC-BY-NC-ND 4.0 International license .

observation was that relative abundances of Bacteroidetes increased and Firmicutes decreased in successful abstainers, however, we observed the reverse pattern in the continuing smoker group. We did not observe significant changes in alpha- or beta-diversity with smoking cessation. Overall, these findings represent relatively minor effects of smoking cessation on the microbiome.

An increased Bacteroidetes:Firmicutes ratio has been observed in several disease states that increase cardiovascular disease risk.[3,6,14-17] Increases in Bacteroidetes may increase lipopolysaccharide production which may upregulate inflammatory pathways.[18] Bacteroidetes also produce gut acetate, which is readily absorbed and can be used for cholesterol production.[14] Very few studies have examined the fecal microbiome of smokers after cessation. An observational study of 10 smokers suggested that smoking cessation led to a decrease in the Bacteroidetes:Firmicutes ratio.[6] A cross-sectional study that evaluated 758 men classified as never, current, or former smokers showed an increased Bacteroidetes: Firmicutes ratio in fecal microbiomes of current smokers compared to never smokers and former smokers, although there was no difference in this ratio between the never and former smokers groups.[20]

In a small study, smoking cessation was associated with a short-term increase in alphadiversity.[15] We did not observe significant changes in alpha- or beta-diversity with smoking cessation.

This pilot study had several limitations including a relatively small sample size, though to our knowledge, this is the largest study of smoking and cessation on the fecal microbiota to date. Follow-up was 12 weeks and several subjects dropped out, as is common in studies of smoking cessation pharmacotherapy, so we can't exclude a more long-term effect of smoking cessation. This study was limited to current smokers making a quit attempt, so we cannot compare our findings to non-smokers.

\section{CONCLUSIONS}

Smoking cessation has minor effects on the composition of the gut microbiome. Among current smokers, relative abundances of the phylum Actinobacteria were associated inversely with pack-years of smoking and abundances of the phylum Cyanobacteria were associated directly with $\mathrm{CO}$ levels. In successful abstainers, relative abundances of the phyla Bacteroidetes increased and Firmicutes decreased, a pattern of uncertain clinical significance. We did not observe significant changes in alpha- or beta-diversity with smoking cessation. It is unclear if the proven health benefits of smoking cessation lead to salutary changes in the intestinal microbiota and if such changes affect cardiovascular disease risk. 
medRxiv preprint doi: https://doi.org/10.1101/2020.07.11.20151480; this version posted July 14, 2020. The copyright holder for this preprint

(which was not certified by peer review) is the author/funder, who has granted medRxiv a license to display the preprint in perpetuity.

It is made available under a CC-BY-NC-ND 4.0 International license.

\section{Funding}

The QUITS study was funded by grant 2 R01 HL109031 from the National, Heart, Lung, and Blood Institute. T-W.L.C was supported by a National Institutes of Health Ruth L. Kirschstein National Research Service Award T32 HL 007936 from the National Heart Lung and Blood Institute to the University of Wisconsin-Madison Cardiovascular Research Center. SLH and ZW were supported by grants P01HL147823 and R01HL103866 from the NIH and Office of Dietary supplements. SLH and FR were also partially supported by an award from the Leducq Foundation.

\section{Declaration of Interests}

Marcus G. Sublette, MD: None

Tzu-Wen L. Cross, PhD, RD: None

Claudia E. Korcarz, DVM: None

Kristin M. Hansen, BS: None

Sofia M. Murga-Garrido, MD: None

Stanley L. Hazen, MD, PhD: Co-inventor on pending and issued patents held by the Cleveland Clinic relating to cardiovascular diagnostics and therapeutics; royalty payments for inventions or discoveries related to cardiovascular diagnostics or therapeutics from Cleveland Heart Lab and Procter \& Gamble; paid consultant for Procter \& Gamble; received research funds from Procter \& Gamble, Pfizer Inc., and Roche Diagnostics

Zeneng Wang, PhD: Co-inventor on pending and issued patents held by the Cleveland Clinic relating to cardiovascular diagnostics and therapeutics; royalty payments for inventions or discoveries related to cardiovascular diagnostics or therapeutics from Cleveland Heart Lab and Procter \& Gamble Madeline K. Oguss, MS: None Federico E. Rey, PhD: None James H. Stein, MD, FAHA: None 
medRxiv preprint doi: https://doi.org/10.1101/2020.07.11.20151480; this version posted July 14, 2020. The copyright holder for this preprint

(which was not certified by peer review) is the author/funder, who has granted medRxiv a license to display the preprint in perpetuity.

It is made available under a CC-BY-NC-ND 4.0 International license .

\section{References}

1. Wang Z, Klipfell E, Bennett BJ, et al. Gut flora metabolism of phosphatidylcholine promotes cardiovascular disease. Nature. 2011; 472: 57-63.

2. Koeth RA, Wang Z, Levison BS, et al. Intestinal microbiota metabolism of I-carnitine, a nutrient in red meat, promotes atherosclerosis. Nat Med. 2013; 19: 576-585.

3. Savin Z, Kivity S, Yonath H, Yehuda S. Smoking and the intestinal microbiome. Arch Microbiol. 2018; 200: 677-684.

4. Sapkota AR, Berger S, Vogel TM. Human pathogens abundant in the bacterial metagenome of cigarettes. Environ Health Perspect. 2010; 118: 351-356.

5. Benjamin JL, Hedin CR, Koutsoumpas A, et al. Smokers with active crohn's disease have a clinically relevant dysbiosis of the gastrointestinal microbiota. Inflamm Bowel Dis. 2012; 18: 1092-1100.

6. Biedermann L, Zeitz J, Mwinyi J, et al. Smoking cessation induces profound changes in the composition of the intestinal microbiota in humans. PLoS One. 2013; 8: e59260.

7. Kreznar JH, Keller MP, Traeger LL, et al. Host genotype and gut microbiome modulate insulin secretion and diet-induced metabolic phenotypes. Cell Rep. 2017; 18: 17391750.

8. Bolyen E, Rideout JR, Dillon MR, et al. Reproducible, interactive, scalable and extensible microbiome data science using qiime 2. Nat Biotechnol. 2019; 37: 852-857.

9. Callahan BJ, McMurdie PJ, Rosen MJ, Han AW, Johnson AJ, Holmes SP. Dada2: Highresolution sample inference from illumina amplicon data. Nat Methods. 2016; 13: 581583.

10. McDonald D, Price MN, Goodrich J, et al. An improved greengenes taxonomy with explicit ranks for ecological and evolutionary analyses of bacteria and archaea. ISME J. 2012; 6: 610-618.

11. Bokulich NA, Kaehler BD, Rideout JR, et al. Optimizing taxonomic classification of marker-gene amplicon sequences with qiime 2's q2-feature-classifier plugin. Microbiome. 2018; 6: 90.

12. Pielou EC. The measurement of diversity in different types of biological collections. $J$ Theoretical Biol. 1966; 13: 131-144.

13. Lozupone $\mathrm{C}$, Knight R. Unifrac: A new phylogenetic method for comparing microbial communities. Appl Environ Microbiol. 2005; 71: 8228-8235.

14. Kasselman LJ, Vernice NA, DeLeon J, Reiss AB. The gut microbiome and elevated cardiovascular risk in obesity and autoimmunity. Atherosclerosis. 2018; 271: 203-213.

15. Ley RE, Turnbaugh PJ, Klein S, Gordon JI. Microbial ecology: Human gut microbes associated with obesity. Nature. 2006; 444: 1022-1023.

16. Hevia A, Milani C, Lopez $P$, et al. Intestinal dysbiosis associated with systemic lupus erythematosus. mBio. 2014; 5: e01548-01514.

17. Giongo A, Gano KA, Crabb DB, et al. Toward defining the autoimmune microbiome for type 1 diabetes. ISME J. 2011; 5: 82-91.

18. Boulange CL, Neves AL, Chilloux J, Nicholson JK, Dumas ME. Impact of the gut microbiota on inflammation, obesity, and metabolic disease. Genome Med. 2016; 8: 42.

19. Jacobson AN, Choudhury BP, Fischbach MA. The biosynthesis of lipooligosaccharide from bacteroides thetaiotaomicron. mBio. 2018; 9: e02289.

20. Lee SH, Yun Y, Kim SJ, et al. Association between cigarette smoking status and composition of gut microbiota: Population-based cross-sectional study. J Clin Med. 2018; 7: 282. 
medRxiv preprint doi: https://doi.org/10.1101/2020.07.11.20151480; this version posted July 14, 2020. The copyright holder for this preprint (which was not certified by peer review) is the author/funder, who has granted medRxiv a license to display the preprint in perpetuity.

It is made available under a CC-BY-NC-ND 4.0 International license .

Table 1. Participant Characteristics at Baseline $(\mathrm{N}=36)$

\begin{tabular}{|c|c|c|c|}
\hline Variable & Mean & $\begin{array}{l}\text { Standard } \\
\text { Deviation }\end{array}$ & Range \\
\hline Age (years) & 51.4 & 11.2 & $26-71$ \\
\hline Male (\%) & 42.0 & - & - \\
\hline Cigarettes/day & 15.1 & 6.4 & $5.1-35.0$ \\
\hline Pack-years & 22.7 & 12.0 & $2.5-52.0$ \\
\hline Exhale Carbon monoxide (ppm) & 17.6 & 9.3 & $5-41$ \\
\hline Body-mass index $\left(\mathrm{kg} / \mathrm{m}^{2}\right)$ & 29.6 & 8.4 & $20.7-67.9$ \\
\hline Heart rate $(\mathrm{bpm})$ & 72.3 & 10.7 & $57-100$ \\
\hline Systolic blood pressure $(\mathrm{mmHg})$ & 131.4 & 16.5 & $102-162$ \\
\hline Diastolic blood pressure $(\mathrm{mmHg})$ & 77.6 & 9.0 & $66-95$ \\
\hline Non-high-density lipoprotein cholesterol & 160.3 & 52.6 & $69-274$ \\
\hline Glucose $(\mathrm{mg} / \mathrm{dL})$ & 92.4 & 9.7 & $70-109$ \\
\hline C-reactive protein (mg/L) & 4.6 & 7.5 & $0.1-39.5$ \\
\hline Trimethylamine $\mathrm{N}$-oxide (microM) & 3.75 & 2.11 & $1.11-13.18$ \\
\hline White blood cell count $(\mathrm{K} / \mu \mathrm{L})$ & 8.4 & 2.2 & $4.6-13.9$ \\
\hline Carotid-femoral pulse wave velocity $(\mathrm{m} / \mathrm{s})$ & 7.46 & 1.84 & $4.80-12.95$ \\
\hline Brachial artery flow-mediated dilation (\%) & 4.57 & 2.91 & $0.55-12.05$ \\
\hline Carotid plaque score $(0-12)$ & 3.0 & 2.8 & $0-10$ \\
\hline \multicolumn{4}{|l|}{ Microbiota Relative Abundances (\%) } \\
\hline Actinobacteria & 4.17 & 4.37 & $0.0-15.90$ \\
\hline Cyanobacteria & 0.04 & 0.13 & $0.0-0.72$ \\
\hline Verrucomicrobia & 0.70 & 2.55 & $0.0-14.41$ \\
\hline Euryarchaeota & 0.10 & 0.24 & $0.0-0.96$ \\
\hline Bacteroidetes & 23.40 & 10.5 & $8.10-49.30$ \\
\hline Firmicutes & 70.20 & 10.0 & $46.10-88.70$ \\
\hline Fusobacteria & 0.011 & 0.44 & $0.0-2.52$ \\
\hline Proteobacteria & 1.26 & 1.02 & $0.0-5.70$ \\
\hline \multicolumn{4}{|l|}{ Alpha-Diversity Measures (units) } \\
\hline Pielou's evenness & 0.77 & 0.06 & $0.58-0.84$ \\
\hline Faith PD & 8.32 & 1.68 & $4.78-12.11$ \\
\hline Shannon & 5.14 & 0.60 & $3.05-6.12$ \\
\hline
\end{tabular}


Table 2. Effect of Quit Attempt on Changes in Bacterial Abundance and Diversity Measures from Baseline to Week 12

\begin{tabular}{|l|c|c|c|}
\hline \multicolumn{1}{|c|}{ Change Variable } & Beta & Standard Error & P-value \\
\hline Microbiota Relative Abundances (\%) & & & \\
\hline Actinobacteria & 1.2 & 0.8 & 0.15 \\
\hline Cyanobacteria & 0.0 & 0.0 & 0.17 \\
\hline Verrucomicrobia & 0.0 & 0.1 & 0.92 \\
\hline Euryarchaeota & 0.0 & 0.4 & 0.99 \\
\hline Bacteroidetes & 7.4 & 3.5 & $\mathbf{0 . 0 4 8}$ \\
\hline Firmicutes & -7.6 & 3.4 & $\mathbf{0 . 0 3 6}$ \\
\hline Fusobacteria & -0.1 & 0.1 & 0.53 \\
\hline Proteobacteria & 0.3 & 0.6 & 0.67 \\
\hline Alpha-Diversity Measures (units) & & & \\
\hline Pielou's evenness & -0.01 & 0.02 & 0.61 \\
\hline Faith PD & -0.10 & 0.85 & 0.91 \\
\hline Shannon & -0.13 & 0.23 & 0.59 \\
\hline
\end{tabular}


medRxiv preprint doi: https://doi.org/10.1101/2020.07.11.20151480; this version posted July 14, 2020. The copyright holder for this preprint (which was not certified by peer review) is the author/funder, who has granted medRxiv a license to display the preprint in perpetuity.

It is made available under a CC-BY-NC-ND 4.0 International license. 
$\square$ Bacteroidetes-Baseline $\square$ Bacteroidetes-Week 12

$\square$ Firmicutes-Baseline $\quad \square$ Firmicutes-Week 12

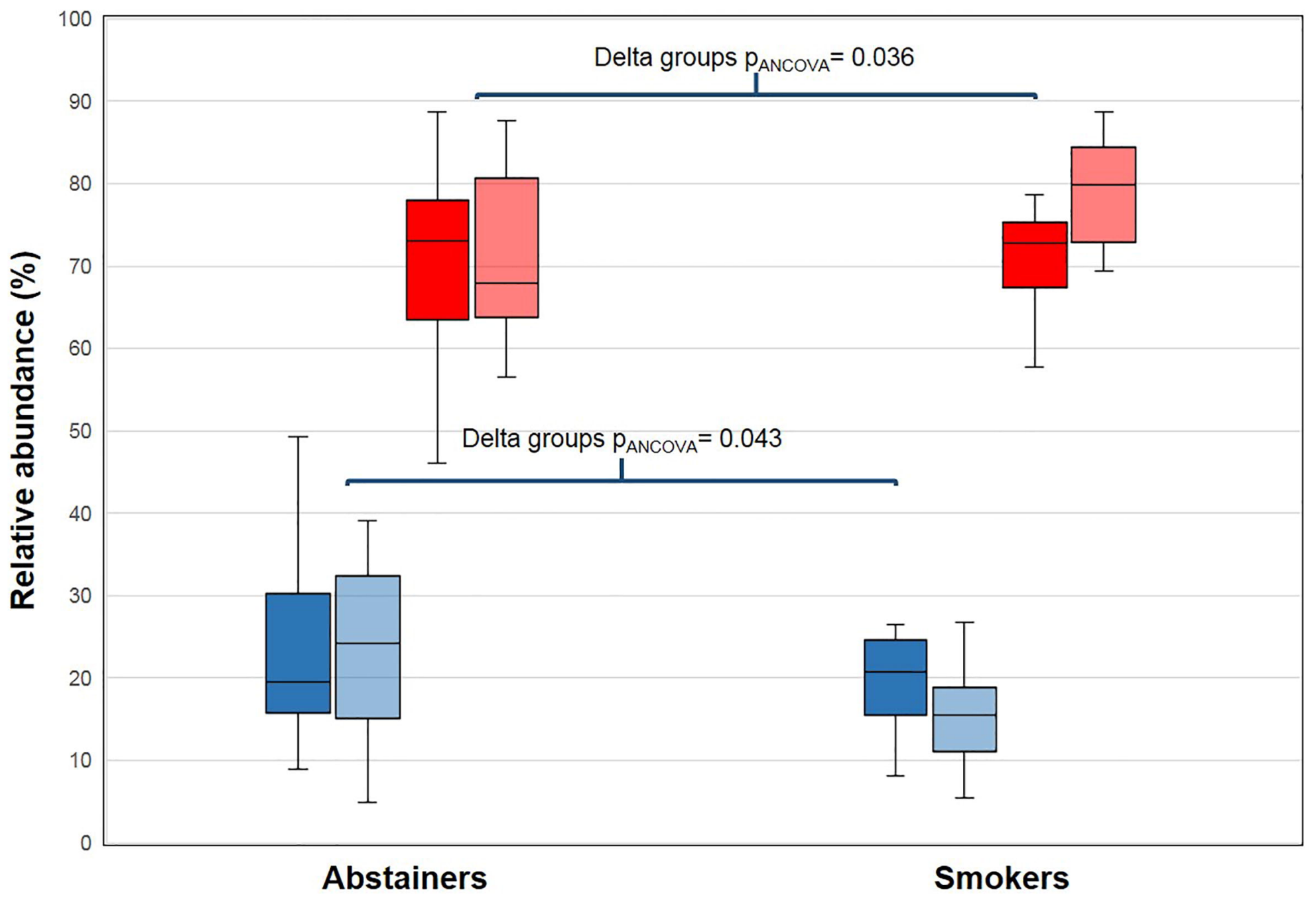

